\title{
Lypsylehmien aminohappojen saanti säilörehuruokinnalla
}

Mikko Korhonen

Kemira Growhow, Mechelininkatu 1a,PL 900,00181 Helsinki,mikko.korhonen@kemira-growhow.com

\section{Johdanto}

Lypsylehmien ruokinta perustuu Suomessa pääosin nurmisäilörehuun ja viljaan joita täydennetään valkuaisrehuilla. Märehtijöiden erityispiirre on pötsissä tapahtuva mikrobitoiminta minkä seurauksena eläimen käyttöön tulevien ravintoaineiden määrä poikkeaa rehussa saatujen ravintoaineiden määrästä. Mikrobitoiminnan vuoksi aminohappojen saanti muodostuu sekä mikrobivalkuaisesta että rehun hajoamattomasta valkuaisesta. Koska kudosten typen tarve on aminohappojen tarvetta, niiden saannilla on keskeinen merkitys rehuvalkuaisen hyväksikäytössä.

Nykyisin käytetyssä märehtijöiden valkuaisarvojärjestelmässä (OIV/PVT ohutsuolesta imeytyvät aminohapot/pötsin valkuaistase) aminohappojen saannin arviointi perustuu rehujen pötsissä hajoamattoman valkuaisen ja pötsissä syntetisoituvan mikrobivalkuaisen yhteismäärään eli aminohappojen kokonaissaantiin (Tuori ym. 2000). Viimeaikaiset kokeet ovat osoittaneet että maidontuotantoa ja rehutypen hyväksikäyttöä voidaan tehostaa yksittäisten aminohappojen lisäyksillä (Guinard ja Rulquin, 1995). Yksittäisten aminohappojen saannin ja tarpeen huomioiminen valkuaisarvojärjestelmissä nykyisen kokonaisaminohappojen saannin ja tarpeen sijaan vaatii kuitenkin tarkkoja mittauksia aminohappojen saannista erilaisilla ruokinnoilla sekä tietoa siitä mikä tai mitkä aminohapot ovat maidontuotantoa eniten rajoittavia aminohappoja. Maissisäilörehuun ja/tai sinimailaseen perustuvalla ruokinnalla metioniini ja lysiini ovat maidontuotantoa eniten rajoittavia aminohappoja (Schwab ym. 1976, Guinard ja Rulquin, 1995) ja niiden saannista on runsaasti tietoa. Nurmisäilörehuruokinnalla sen sijaan ensimmäiseksi maidontuotantoa rajoittavaksi aminohapoksi on osoittautunut histidiini (Vanhatalo ym. 1999), mutta aminohappojen saantia ei ole aikaisemmin systemaattisesti määritetty.

\section{Aineisto ja menetelmät}

Jokioisilla toteutetussa tutkimusprojektissa tutkittiin lypsylehmien aminohappojen saantia nurmisäilörehuun perustuvalla ruokinnalla (Korhonen, 2003). Tutkimuksissa selvitettiin mikä merkitys aminohappojen määrällisellä ja laadullisella saannilla on maidontuotantoon ja ravintoaineiden hyväksikäyttöön lypsylehmillä ja millaisilla ruokinnallisilla tekijöillä voidaan vaikuttaa aminohappojen saantiin.

Kokeet toteutettiin $4 \times 4$ tai $5 \times 5$ latinalaisen neliön koejärjestelyn mukaisesti, jossa koejaksojen pituudet olivat 14 tai 28 pv. Kaikissa kokeissa lehmät saivat perusrehuna happosäilöttyä nurmisäilörehua pelkästään tai täydennettynä viljalla (ohra tai ohra-kaura). Valkuaisrehujen vaikutusta aminohappojen saantiin tutkittiin rypsi-, soija-, kalajauho- ja maissigluteenitäydennyksillä. Aminohappojen saanti arvioitiin pötsistä virtaavan ruokasulan määrän ja sen aminohappokoostumuksen avulla. Ruokasulan virtaus määritettiin kolmoismerkkiainemenetelmällä. Ruokasulanäyte otettiin satakertanäytteenottotekniikalla (Ahvenjärvi ym. 2000). Mikrobivalkuaisen virtauksen arvioinnissa merkkiaineena käytettiin ${ }^{15} \mathrm{~N}$ :a. Kaikissa kokeissa mitattiin myös maitotuotos sekä ravintoaineiden sulavuus ja pötsifermentaatio ravintoaineiden saannin selvittämiseksi. Aminohappojen saannin lisäksi tutkittiin maitorauhasen aminohappojen metaboliaa.

\section{Pötsistä virtaavan ruokasulan aminohappokoostumus}

Satakerrasta otetun ruokasulan aminohappokoostumus (\% kokonaisaminohapoista) oli eri kokeissa hyvin samanlainen (Kuva 1). Erot histidiinin, metioniinin, isoleusiinin ja fenyylialaniinin pitoisuuksissa johtuivat todennäköisimmin siitä, että yhdessä kokeessa nurmisäilörehu tehtiin nurmi-apilakasvustosta. Maissiruokintaan verrattuna (Kuva 2) suurimmat erot ovat leusiinin, metioniinin ja isoleusiinin pitoisuuksissa. Tämä vahvistaa sitä, että aminohappojen saanti on riippuvainen perusruokinnasta. Aminohappojen saannin ero on yhdenmukainen myös aminohappojen infuusiokokeiden tulosten kanssa, joiden mukaan metioniinilla on saatu tuotosvasteita maissiruokinnalla (Guinard ja Rulquin. 1995) mutta ei nurmisäilörehuruokinnalla (Vanhatalo ym. 1999). 


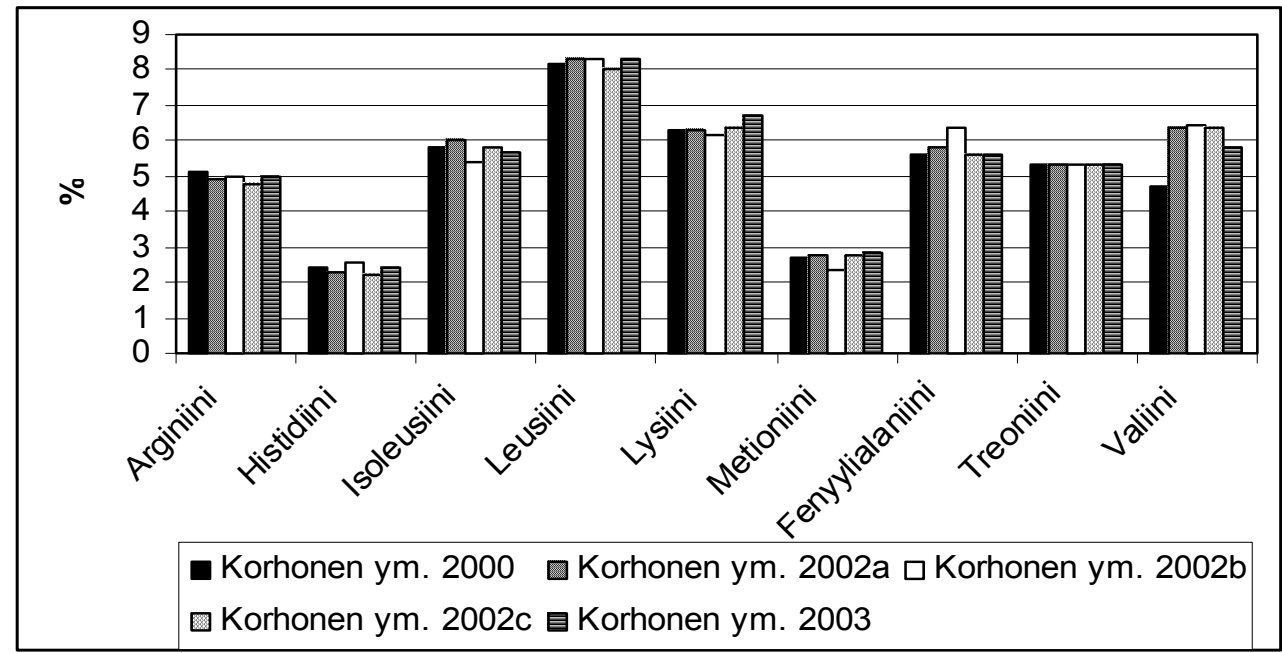

Kuva 1. Pötsistä virtaavan ruokasulan aminohappokoostumus nurmisäilörehuruokinnalla

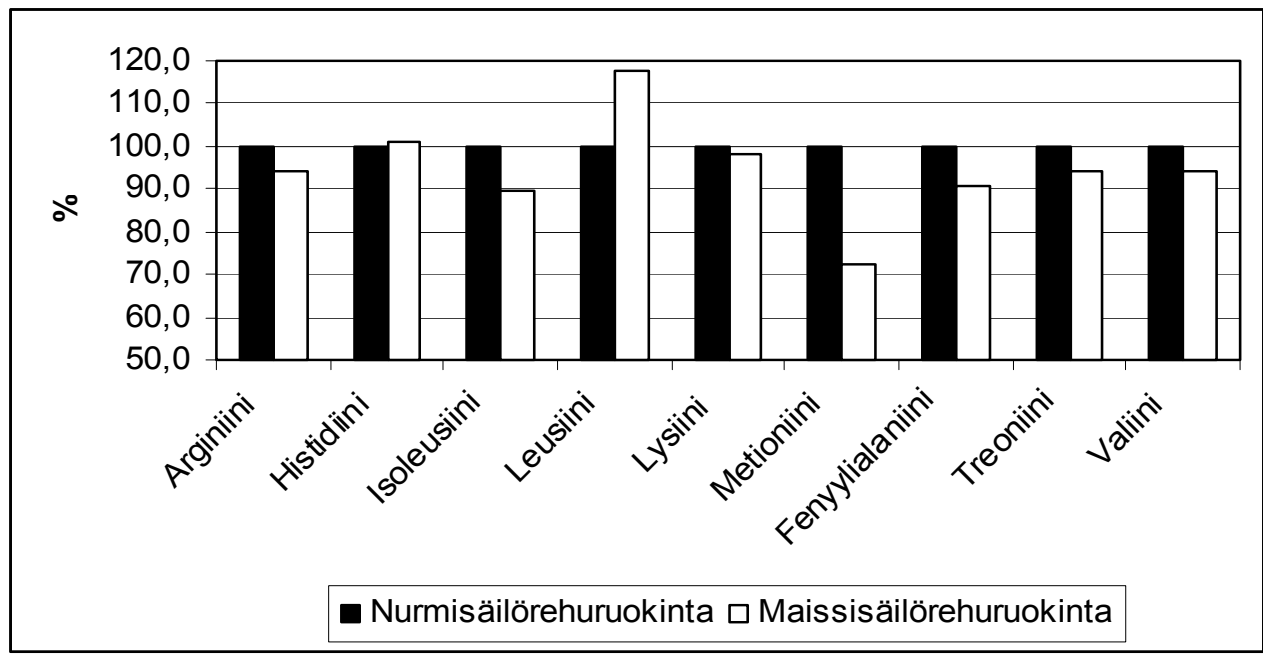

Kuva 2. Ruokasulan aminohappokoostumuksen erot maissi- (Schwab ym. 1992) ja nurmisäilörehuruokinnalla (Korhonen, 2003).

Maissisäilörehu sekä maissiruokinnalla käytetyt valkuaistäydennykset eivät ole erityisen hyviä lysiinin ja metioniinin lähteitä (Shingoethe, 1996), mutta sisältävät runsaasti leusiinia. Lisäksi valkuaistäydennys maissiruokinnalla vähentää mikrobivalkuaisen osuutta ohutsuoleen tulevan valkuaisen kokonaismäärästä (Santos ym. 1998). Nurmisäilörehuruokinnalla mikrobivalkuaisen osuus pysyy sen sijaan korkeana huolimatta ohitusvalkuaisen osuuden lisääntymisestä. Mikrobivalkuaisen osuus oli perusruokinnalla 60 $75 \%$. Tämän vuoksi nurmisäilörehuruokinnalla imeytyvän valkuaisen aminohappokoostumus on enemmän riippuvainen mikrobivalkuaisen aminohappokoostumuksesta, jolloin myös ohitusvalkuaisen aminohappokoostumuksen muuttumisen vaikutus ruokasulan aminohappokoostumukseen on vähäisempi. Aminohappokoostumuksen lisäksi toinen aminohappojen lisäyksien erilaisia tuotosvasteita selittävä tekijä saattaa olla aminohappojen saannin kokonaismäärä, mikä vaihteli koostumusta enemmän, huolimatta samantyyppisistä perusruokinnoista.

\section{Mikrobivalkuaisen aminohappokoostumus}

Mikrobivalkuaisen aminohappokoostumus oli ruokinnasta riippumatta vakio (Kuva 3). Mikrobivalkuaisesta peräisin olevien aminohappojen saannin arvioinnissa mikrobinäytteiden jaottelu neste- ja partikkelifaasin bakteereihin ja alkueläimiin voi parantaa mikrobivalkuaisen virtauksen 
arvioinnin tarkkuutta, mutta sillä ei ollut merkittävää vaikutusta mikrobivalkuaisen aminohappokoostumukseen.

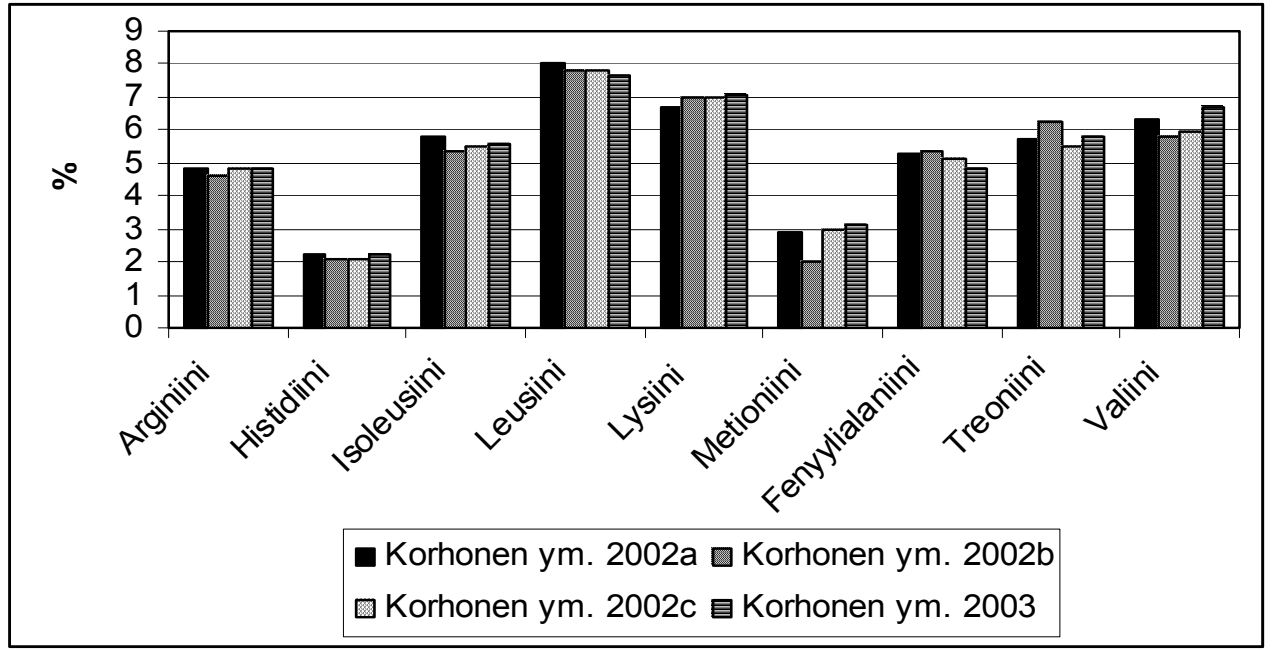

\section{Kuva 3. Mikrobivalkuaisen aminohappokoostumus nurmisäilörehuruokinnalla.}

Runsas mikrobivalkuaisen osuus ja se, että mikrobivalkuaisen histidiinipitoisuus on selvästi metioniinipitoisuutta pienempi (Kuva 3, Taulukko 1) selittää ja vahvistaa sitä, että histidiini on maidontuotantoa ensimmäiseksi rajoittava aminohappo nurmisäilörehuruokinnalla.

Taulukko 1. Rehujen aminohappokoostumukset ja ruokinnan vaikutus ruokasulan aminohappokoostumukseen.

\begin{tabular}{llllllll}
\hline & $\begin{array}{l}\text { Mikrobi- } \\
\text { valkuainen }\end{array}$ & Säilörehu & Ohra & Rypsi & Soija & $\begin{array}{l}\text { Maissi- } \\
\text { gluteeni }\end{array}$ & $\begin{array}{l}\text { Kala- } \\
\text { jauho }\end{array}$ \\
\hline Rehussa, g/100 g AH & & & & & & & \\
Histidiini & 2.2 & 2.6 & 2.5 & 3.1 & 2.8 & 1.9 & 2.6 \\
Metioniini & 2.8 & 2.5 & 1.8 & 2.3 & 1.4 & 1.9 & 3.0 \\
Lysiini & 7.0 & 9.2 & 3.8 & 6.1 & 6.6 & 1.6 & 8.6 \\
Ruokasulassa, g/100 g AH & & SR-vilja & & SR-rypsi & SR-soija & SR-MG & SR-KJ \\
Histidiini & & 2.4 & & 2.5 & 2.3 & 2.3 & 2.2 \\
Metioniini & & 2.7 & & 2.6 & 6.9 & 5.2 & 6.4 \\
Lysiini & 6.4 & & 6.3 & 2.9 & 2.6 & 2.6 \\
\hline
\end{tabular}

\section{Ohra- ja valkuaistäydennyksen vaikutus aminohappojen saantiin}

Ohratäydennys lisäsi aminohappojen saantia lisäämällä mikrobivalkuaisen virtausta pötsistä, mutta ei parantanut typen hyväksikäyttöä pötsissä (Ahvenjärvi ym. 2002, Korhonen ym. 2003). Aminohappojen virtausten perusteella laskettuna aminohappojen saannin lisäys oli selvästi pienempi kuin oletettu OIVarvo. Tämä saattaa johtua oletettua vähäisemmästä mikrobien energian saannin lisääntymisestä tärkkelyksen ohivirtauksen vuoksi tai NDF-kuidun alentuneesta sulavuudesta väkirehun osuuden noustessa (Ahvenjärvi ym. 2002). Kolmas selittävä tekijä saattaa olla ohran oletettua suurempi pötsihajoavuus, mikä lisää koko dieetin pötsihajoavuutta.

Valkuaistäydennykset lisäsivät aminohappojen kokonaisvirtausta pötsistä lisäämällä rehuperäisten aminohappojen virtausta, mikä on yhtenevä tulos aikaisempien kokeiden kanssa (O'Mara ym. 1998). Tämä viittaa siihen, että huolimatta ohitusvalkuaisen osuuden lisääntymisestä rehussa, hajoavan valkuaisen saanti pysyy riittävänä, eli mikrobivalkuaissynteesi ei vähene kuten maissiruokinnoilla (Santos ym. 1998). Tutkituista valkuaisrehuista (rypsi, soija, kalajauho, maissigluteeni) soijan aminohappojen saantia lisäävä vaikutus oli vähäisintä ja maissigluteenin suurinta, mikä on yhdenmukainen valkuaisen pötsihajoavuuksien kanssa (Tuori ym. 2000). Soijan vaikutus aminohappojen saantiin oli myös oletettua vähäisempi, johtuen sen suuremmasta pötsihajoavuudesta. Tämä tukee myös tuotantokokeen tulosta (Shinfield ym. 2002), jonka mukaan soija oli selvästi rypsiä huonompi maidontuotannossa. 
Ohitusvalkuaisen osuuden lisääntyminen verrattuna perusruokintaan sekä valkuaistäydennyksen aminohappokoostumus heijastui jonkin verran myös ruokasulan aminohappokoostumukseen (Taulukko 1).

\section{Aminohappojen pötsihajoavuus}

Valkuaisarvojärjestelmässä (Tuori ym. 2000) oletetaan että aminohappojen pötsihajoavuus on sama kuin rehuvalkuaisen pötsihajoavuus. Tämänkin projektin kokeiden tulokset, kuten myös jotkut aikaisemmat tulokset, ovat kuitenkin viitanneet siihen, että ohitusvalkuaisen aminohappokoostumus voi poiketa rehun aminohappokoostumuksesta eli että hajoavuudet voisivat olla erilaisia. Tästä ei kuitenkaan voi tehdä selviä johtopäätöksiä, mutta hajoavuuksien selvittäminen on tärkeää, jotta saadaan lisää tietoa yksittäisten aminohappojen laskennallisen saannin pohjaksi.

\section{Johtopäätökset}

Nurmisäilörehuruokinnalla aminohappojen määrällisessä saannissa on jonkin verran vaihtelua mutta ruokasulan aminohappokoostumus on melko vakio. Tämä johtuu siitä, että ruokinta ei vaikuta mikrobivalkuaisen aminohappokoostumukseen ja että mikrobivalkuaisen osuus pötsistä virtaavasta valkuaisesta on yli $60 \%$. Mikrobivalkuaisen jaottelu alkueläimiin, sekä partikkeli- ja nestefaasin bakteereihin voi lisätä mikrobivalkuaisen saannin määrityksen tarkkuutta, mutta sillä ei ole vaikutusta mikrobivalkuaisen aminohappokoostumukseen. Ohra lisää aminohappojen saantia mikrobivalkuaisen kautta kun taas valkuaistäydennykset lisäävät ohitusvalkuaisen virtausta. Valkuaisrehujen välisen eron aminohappojen kokonaissaannissa selitti rehujen pötsihajoavuus (soija $<$ rypsi $<$ kalajauho $<$ maissigluteeni). Soijan vaikutus oli oletettua vähäisempi johtuen sen suuremmasta pötsihajoavuudesta. Tulosten perusteella säilörehusta näyttäisi tulevan hieman nykyistä arviota enemmän aminohappoja kun taas ohran OIV-arvo näyttäisi olevan jonkin verran yliarvioitu. Käytännön ruokinnassa aminohappojen saantiin voidaan vaikuttaa valitsemalla sellainen valkuaisrehu, jonka aminohappokoostumus täydentää mikrobivalkuaista ja jonka pötsihajoavuus on vähäinen. Rypsi on hyvä valkuaistäydennys johtuen sen aminohappokoostumuksesta ja rehuvalkuaisen virtausta lisäävästä vaikutuksesta. Yksittäisten aminohappojen saannin soveltaminen käytäntöön vaatii vielä aminohappojen sulavuuksien tarkempaa selvitystä. Tutkimuksen sovellettavuus käytäntöön on pitkälti riippuvainen ympäristöpoliittisista päätöksistä sekä rehun hinnan ja maidon tuottajahinnan suhteista. Nyt tutkimuksessa saatua tietoa aminohappojen saannista ja metaboliasta voidaan käyttää uuden kokonaan dynaamiseen tietokonemallinnukseen perustuvan rehuarvomallin kehitystyössä.

\section{Kirjallisuus}

Ahvenjärvi, S., A. Vanhatalo, P. Huhtanen and T. Varvikko. 2000. Determination of reticulo-rumen and whole stomach digestion in lactating cows by omasal or duodenal sampling. Br. J. Nutr. 83: 67-77.

Ahvenjärvi, S., A. Vanhatalo and P. Huhtanen. 2002. Supplementing barley or rapeseed meal to dairy cows fed grass-red clover silage: 1. Rumen degradability and microbial flow. J. Anim. Sci. 80: 2176-2187.

Korhonen, M. 2003. Amino acid supply and metabolism in relation to lactational performance of dairy cows fed grass silage based diets. Väitöskirja $45 \mathrm{~s}$. Helsingin yliopisto, Kotieläintieteen laitos.

O'Mara, F. P., J. J. Murphy and M. Rath. 1998. Effect of amount of dietary supplement and source of protein on milk production, ruminal fermentation, and nutrient flows in dairy cows. J. Dairy Sci. 81: 2430-2439.

Guinard, J. and H. Rulquin. 1995. Effect of graded amount of duodenal infusions of methionine on the mammary uptake of major milk precursors in dairy cows. J. Dairy Sci. 78: 2196-2207.

Santos, F. A. P., J. E. P. Santos, C. B. Theurer and J. T. Huber. 1998. Effects of rumen-undegradable protein on dairy cow performance: A 12-year literature review. J. Dairy Sci. 81: 3182-3213.

Schingoethe, D. J. 1996. Balancing the amino acid needs of the dairy cow. Anim. Feed Sci. Technol. 60:153-160.

Schwab, C. G, L. D. Satter and A. B. Clay. 1976. Response of lactating dairy cows to abomasal infusion of amino acids. J. Dairy Sci. 59: 1254-1270.

Shingfield, K. J., A. Vanhatalo and P. Huhtanen. 2002. Comparison of rapeseed and soybean protein supplments on the intake and milk production of dairy cows fed grass silage-based diets. In: L. M. Gechie and C. Thomas (ed.) Proceedings of the $13^{\text {th }}$ International Silage Conference, Auchincruive, Scotland p.314.

Tuori, M., K. Kaustell, J. Valaja, E. Aimonen, E. Saarisalo and P. Huhtanen. 2000. Rehutaulukot ja ruokintasuositukset. [Feed tables and feeding recommendations, third edition.] Yliopistopaino, Helsinki, Finland. Vanhatalo, A., P. Huhtanen, V. Toivonen and T. Varvikko. 1999. Response of dairy cows fed grass silage diets to abomasal infusions of histidine alone or in combinations with methionine and lysine. J. Dairy Sci. 82:2674 2685 . 